Article

\title{
Soil Communities: Who Responds and How Quickly to a Change in Agricultural System?
}

\author{
Emanuela Coller ${ }^{1}$, Claudia Maria Oliveira Longa ${ }^{2, *} \mathbb{*}$, Raffaella Morelli ${ }^{3}$, Sara Zanoni ${ }^{3} \oplus$, \\ Marco Cristiano Cersosimo Ippolito ${ }^{3}$, Massimo Pindo ${ }^{4}$, Cristina Cappelletti ${ }^{3}$, Francesca Ciutti ${ }^{3}$, \\ Cristina Menta ${ }^{1}$, Roberto Zanzotti ${ }^{3}$ (D) and Claudio Ioriatti ${ }^{3}$ (i)
}

check for updates

Citation: Coller, E.; Oliveira Longa,

C.M.; Morelli, R.; Zanoni, S.;

Cersosimo Ippolito, M.C.; Pindo, M.; Cappelletti, C.; Ciutti, F.; Menta, C.; Zanzotti, R.; et al. Soil Communities: Who Responds and How Quickly to a Change in Agricultural

System? Sustainability 2022, 14, 383. https://doi.org/10.3390/su14010383

Academic Editors: Rajan Ghimire and Bharat Sharma Acharya

Received: 28 October 2021

Accepted: 27 December 2021

Published: 30 December 2021

Publisher's Note: MDPI stays neutral with regard to jurisdictional claims in published maps and institutional affiliations.

Copyright: (C) 2021 by the authors. Licensee MDPI, Basel, Switzerland. This article is an open access article distributed under the terms and conditions of the Creative Commons Attribution (CC BY) license (https:// creativecommons.org/licenses/by/ $4.0 /)$.
1 Department of Chemistry, Life Sciences and Environmental Sustainability, University of Parma, Parco Area delle Scienze 11/A, 43124 Parma, Italy; coller.emanuela@gmail.com (E.C.); cristina.menta@unipr.it (C.M.)

2 Department of Sustainable Agroecosystems and Bioresources, Research and Innovation Centre, Edmund Mach Foundation, Via E. Mach 1, 38098 San Michele all'Adige, Italy

3 Technology Transfer Centre, Edmund Mach Foundation, Via E. Mach 1, 38098 San Michele all'Adige, Italy; raffaella.morelli@fmach.it (R.M.); sara.zanoni@fmach.it (S.Z.); marco.cersosimoippolito@fmach.it (M.C.C.I.); cristina.cappelletti@fmach.it (C.C.); francesca.ciutti@fmach.it (F.C.); roberto.zanzotti@fmach.it (R.Z.); claudio.ioriatti@fmach.it (C.I.)

4 Computational Biology, Research and Innovation Centre, Edmund Mach Foundation, Via E. Mach 1, 38098 San Michele all'Adige, Italy; massimo.pindo@fmach.it

* Correspondence: claudia.longa@fmach.it; Tel.: +39-0461-615508

\begin{abstract}
The use of conservation and sustainable practices could restore the abundance and richness of soil organisms in agroecosystems. Fitting in this context, this study aimed to highlight whether and how different soil living communities reacted to the conversion from an integrated to an organic orchard. The metataxonomic approach for fungi and bacteria and the determination of biological forms of diatoms and microarthropods were applied. Soil analyses were carried out in order to evaluate the effect of soil chemical features on four major soil living communities. Our results showed that the different taxa reacted with different speeds to the management changes. Fungi responded quickly to the changes, suggesting that modification in agricultural practices had a greater impact on fungal communities. Bacteria and microarthropods were more affected by abiotic parameters and less by the management. The diatom composition seemed to be affected by seasonality but the highest $\mathrm{H}^{\prime}$ (Shannon index) value was measured in the organic system. Fungi, but also diatoms, seemed to be promising for monitoring changes in the soil since they were sensitive to both the soil features and the anthropic impact. Our study showed that soil biodiversity could be affected by the conversion to sustainable management practices from the early years of an orchard onwards. Therefore, better ecological orchard management may strengthen soil sustainability and resilience in historically agricultural regions.
\end{abstract}

Keywords: soil biodiversity; bacteria; fungi; microarthropods; diatoms; metataxonomic assays

\section{Introduction}

Soil hosts the most representative fraction of the agroecosystem biodiversity. Its communities are among the more diversified and comprise a wide range of living organisms. They are involved in a large number of ecological processes and play key roles for human populations and agriculture [1]. The long history of intensive agriculture and the consequent recurring use of pesticides, herbicides and mineral fertilizers have compromised soil quality and biological diversity [2]. The use of chemical products against plant pathogens, pests and weeds was shown to affect the chemical and biological fertility of soils in several cases, including several potential adverse effects versus non-target organisms [3]. In addition, the long-term and over-application of pesticides cause severe effects on soil ecology and can drastically modify the structure of soil microbial communities, which may 
further impact their functions in soil [4]. Furthermore, the frequent application of mineral fertilization aggravates the decline of soil organic matter, can significantly reduce soil $\mathrm{pH}$, accelerate soil acidification and affects the nitrogen cycle and the diversity and composition of the microbial community [5,6]. In contrast, sustainable and less invasive practices could reduce the negative impact on agroecosystems, restoring the environment and increasing the abundance and richness of groups of microorganisms in soil [7]. In this context, the characterization of soil communities and their interactions are important topics for defining soil health and quality. Edaphic microorganisms are considered good indicators of soil quality because they are very dynamic and respond quickly to changes in soil management, even before most physico-chemical properties, which take longer to change [8]. Within the soil microbiota, fungi and bacteria are among the most dominant components and are affected by seasonality [9], geographical position [10], soil chemical parameters and agronomic managements [11,12]. They are able to overcome environmental modifications by adjusting their metabolic activity, biomass and community structure [13]. As is already known, long-term organic soil management affects not only primary decomposers, namely, bacteria and fungi, but also other representative trophic levels [14]. Among these, soil microarthropods are often used as indicators of soil health owing to their ability to respond to variations in environmental conditions, soil properties and changes in land management [15-18]. Soil arthropods are highly sensitive to the effects of agricultural management practices and there is evidence that organically managed fields contain a greater abundance and diversity of arthropods than conventionally managed ones [19]. In this regard, some authors have recently proposed the use of terrestrial algae communities for the ecological monitoring and assessment of soil quality [20-23]. A previous study reported differences in the community structure of terrestrial diatoms in response to different farming systems [24]. Diatoms have high biological diversity, are sensitive to anthropic disturbances and environmental parameters and respond to agricultural practices [20,24,25].

Knowledge about the impact of agricultural management systems on the soil biotic components is largely available for arable farming, whereas long-term monocultures, including apple orchards, are less studied. The present study aimed to evaluate (1) whether sustainable agricultural management improves soil biological health and quality, and (2) how fast the edaphic community (fungi, bacteria, diatoms and microarthropods) responds to the modifications induced by agronomic practices. For these purposes, a twoyear trial was carried out on an apple orchard in northeastern Italy during the conversion from integrated pest management (IPM) to organic management.

\section{Materials and Methods}

\subsection{Site Description and Agronomic Managements}

The trial was carried out in an apple orchard located in the Trentino region (northeastern Italy) $\left(46^{\circ} 02^{\prime} 47^{\prime \prime} \mathrm{N}, 11^{\circ} 28^{\prime} 19^{\prime \prime} \mathrm{E} ; 400 \mathrm{~m}\right.$ a.s.l.) during two years of experimentation (2018-2019). The field is located on a dejection conoid and detrital, gravitational and colluvial deposits. The parent material is represented by gravels mixed with sands and blocks of limestone-dolomitic nature. The apple orchard was planted with Gala cultivar (Malus $\times$ domestica Borkh), clone Buckeye ${ }^{\circledR}$ trained on an M9 rootstock and it was planted according to a tree spacing of $3.60 \mathrm{~m} \times 1.00 \mathrm{~m}$ (2778 trees/ha) in 2015 . The field was managed with integrated pest management (IPM, which is a form of agriculture aimed at minimizing the use of inputs from outside the farm by implementing a variety of production enterprises) until 2017. The management was characterized by spring mineral fertilization (NPK 14-7-17, $45 \mathrm{~kg} \mathrm{~N} / \mathrm{ha}$ ), chemical pest and weed control of the rows and a subsequent autumnal mechanical weeding. In April 2018, it was divided into two plots, one of which, formed by seven rows in one block of $2500 \mathrm{~m}^{2}$, was converted to organic management according to Reg. EU 2018/848. The other one consisted of nine rows in one block of $3200 \mathrm{~m}^{2}$ and was maintained with integrated management. The different practices were fertilization and weeding of the row (Table S1). In the integrated management plot, mineral fertilizer (NPK 14-7-17) was supplied once a year in spring at a dose of $45 \mathrm{~kg} \mathrm{~N} / \mathrm{ha}$. 
Matured cattle manure was applied in spring 2018 on the organic management plot in an amount that can release $90 \mathrm{~kg} \mathrm{~N} / \mathrm{ha}$ in an available form over two years and bring about $3.2 \mathrm{t} / \mathrm{ha}$ of organic carbon in the soil. In the rows of the integrated plot, chemical weed control was applied during the season, followed by mechanical mowing in autumn. In contrast, only mechanical mowing throughout the season was applied on the rows of the organic plot. There were no differences in Inter-row management between the Integrated and Organic systems. In this area, natural vegetation (permanent grass) was allowed to grow, which was regularly mowed yearly during the spring-summer season.

\subsection{Soil Sampling}

Soil samples were collected along the row (Row) and between the rows (Inter-row) for both management systems at three different times: T0, before the conversion in 2018 and immediately before fertilization (19 April 2018), T1 after six months (17 October 2018) and T2 after 18 months from the conversion (3 October 2019). Ten replicates were collected for each management, position and time. In total, 120 soil samples were analyzed for chemical parameters, fungi, bacteria and microarthropods. Thirty Inter-row samples were collected for diatoms: five soil samples for both managements and for each collection time. The abbreviations for the different plots are as follows: Integrated Inter-row (Int-Ir), Integrated Row (Int-R), Organic Inter-row (Org-Ir) and Organic Row (Org-R).

\subsection{Soil Physicochemical Properties}

For the physicochemical assays, soil was collected from the $0-20 \mathrm{~cm}$ layer, where each soil sample consisted of three cores, which were homogenized to obtain a representative sample. Physicochemical analyses were carried out on the air-dried fine earth fraction $(<2 \mathrm{~mm})$. Soil texture was determined as a percentage of sand $(2 \mathrm{~mm}-50 \mu \mathrm{m})$, silt $(50 \mu \mathrm{m}-2 \mu \mathrm{m})$ and clay $(<2 \mu \mathrm{m})$ via wet sieving and a hydrometric assay of soil dispersant solution (sodium hexametaphosfate). The $\mathrm{pH}$ was measured using a potentiometer in a soil-water suspension ( $w / v 1: 2.5)$. Total carbonates were determined on powdered samples using the volumetric method, measuring $\mathrm{CO}_{2}$ evolved after the addition of $\mathrm{HCl}$ (ISO 10693:1995). The soil organic matter (SOM) was calculated using the organic carbon (conversion factor: 1.724), which was obtained using the difference between the total carbon, measured using Dumas combustion of powdered soil and TCD detection, and total carbonates (ISO 10694:1995). The total nitrogen was measured simultaneously with the total carbon (ISO 13878:1998). The available fraction of elements was extracted in a DTPA solution and $\mathrm{Cu}, \mathrm{Zn}, \mathrm{Pb}, \mathrm{Fe}$ and $\mathrm{Mn}$ were detected using ICP-OES. The cation exchangeable capacity (CEC) was evaluated using ICP-OES determination of $\mathrm{Mg}$ adsorbed on the soil exchangeable surface after monosaturation with $\mathrm{Ba}$ and exchange with $\mathrm{Mg}$ added as $\mathrm{MgSO}_{4}$. The exchangeable fraction of $\mathrm{Mg}, \mathrm{K}$ and $\mathrm{Ca}$ was extracted in ammonium acetate ( $\mathrm{pH}$ 7.00) and detected using ICP-OES. The assay of assimilable $\mathrm{P}$ was carried out using the Olsen method, providing solubilization of $\mathrm{P}$ in a $\mathrm{NaCO}_{3}$ solution and determination using spectrophotometry with the ascorbic acid method. Soluble B was extracted using a hot treatment with a diluted solution of $\mathrm{CaCl}(w / v$ 1:2) and determined using ICP-OES.

\subsection{Soil Living Communities}

For the metataxonomic analysis, soil samples were freeze-dried and sieved with a $0.2 \mathrm{~mm}$ mesh size and stored at $-80{ }^{\circ} \mathrm{C}$ until the DNA extraction. Total DNA was extracted from $0.25 \mathrm{~g}$ of each composite soil sample using the PowerSoil DNA isolation kit (MO BIO Laboratories Inc., Carlsbad, CA, USA) according to the manufacturer's instructions. Total genomic DNA was amplified using primers that are specific to either the bacterial and archaeal 16S rRNA gene or the fungal ITS1 region. The specific bacterial primer set 515F (5'-GTGYCAGCMGCCGCGGTAA-3 $\left.{ }^{\prime}\right)$ and the 806R (5'GGACTACNVGGGTWTCTAAT-3') were used [26] with degenerate bases suggested by Apprill et al. [27] and Parada et al. [28]. Although no approach based on PCR amplification is free from bias, this primer pair was shown to guarantee good coverage of known bacterial 
and archaeal taxa [29]. For the identification of fungi, the internal transcribed spacer 1 (ITS1) was amplified using the primer ITS1F (5'-CTTGGTCATTTAGAGGAA GTAA-3') [30] and ITS2 (5'-GCTGCGTTCTTCATCGAT GC-3') [31]. All the primers included the specific overhang Illumina adapters for the amplicon library construction. DNA purification, indexing, quantification, library preparation for the Illumina MiSeq sequencing (PE300), preprocessing data and subsequent taxonomic classifications of the OTUs were carried out as described previously by Coller et al. [10]. Filtered sequences were clustered into operational taxonomic units (OTUs) at 97\% identity using the de novo greedy algorithm available in MICCA. OTUs were taxonomically classified using the Ribosomal Database Project (RDP) Classifier v2.11 [32]. Raw overlapping ITS paired-end reads were merged and merged sequences with an overlap length smaller than $100 \mathrm{bp}$ and with more than 32 mismatches were discarded. After the primer trimming, merged reads shorter than $150 \mathrm{bp}$ and with an expected error rate higher than $0.5 \%$ were removed. Filtered sequences were clustered at $97 \%$ identity using the de novo greedy algorithm and OTUs were taxonomically classified as described by Coller et al. [10]. To compensate for different sequencing depths, samples were rarefied to an even depth of 24,180 reads for $16 \mathrm{~S}$ and 18,645 for ITS sequences (Supplementary material, Figure S1). Samples with less than the minimum number of reads were discarded.

For microarthropod investigation, $10 \times 10 \times 10 \mathrm{~cm}^{3}$ soil cubes were collected. The extraction of microarthropods and determination of biological forms was conducted as reported by Parisi et al. [33]. The microarthropod community was assessed depending on the taxa composition, abundance (number of individuals $/ \mathrm{m}^{2}$ ) and an index of soil biological quality, namely, QBS-ar (acronym of Soil Biological Quality) [33]. This index is an expeditious tool used to evaluate soil biological quality in agricultural ecosystems, woods, degraded lands and recovery areas [33,34]. It is a metric index based on the concept that the number of microarthropod groups morphologically well-adapted to soil is higher in high-quality soils than in low-quality soils. This index was developed to combine two key aspects regarding soil microarthropods: (i) their presence in the soil, i.e., biodiversity, and (ii) their disappearance in degraded conditions, i.e., sensitivity.

For the diatom analysis, soil cores were collected using a plastic ring (diameter $5.7 \mathrm{~cm}$, depth $4 \mathrm{~cm}$ ). Diatoms were extracted by rinsing the soil surface with sparkling water to detach the diatoms [23] for a total volume of $50 \mathrm{~mL}$ and preserved in $70 \%$ ethanol according to the standard method proposed by Barragàn et al. [21]. Samples were then treated via oxidation with hydrogen peroxide $35 \%$ to obtain clean frustules and mounted with Naphrax ${ }^{\circledR}$ for slide preparation (EN 13946, European Committee for Standardization 2003). The analysis was conducted at the genus level by counting 200 valves using Olympus BX51 light microscope $(\mathrm{LM})$ at $1000 \times$ magnification and DIC microscopy due to the presence of small species that required scanning electron microscopy SEM to be identified.

\subsection{Statistical Analysis}

The statistical analyses were performed using R software version 3.6.0 [35] and the vegan $\mathrm{R}$ package. The Wilcoxon non-parametric statistical test with the Benjamini-Yekutieli FDR correction ( $p$-value $\leq 0.05)$ was run in order to identify which parameters significantly differed between the different conditions. For the different communities, richness estimators (Species number (S) and S.Chao1) and evenness indices (Shannon (H) and Pielou's (J)) were determined using specnumber, estimateR and diversity functions respectively. In order to obtain the overall variance in life-form compositions, the similarities in the OTU composition of bacteria and fungi, the taxa of microarthropods and the genera of diatoms across samples were visualized using nonmetric multidimensional scaling (NMDS) ordinations based on Bray-Curtis dissimilarity with 999 permutations (metaMDS function). An analysis of similarities (ANOSIM) with 999 permutations based on the Bray-Curtis dissimilarity was conducted to identify differences in organism composition at the three times of sampling in different conditions (vegdist function) (value $0=$ identical samples, value 1 = completely disjointed samples). The correlation analysis was used to determine 
the biotic-biotic interactions and biotic-abiotic interactions. In detail, the Mantel tests were performed to evaluate the Spearman rank correlations between each two-distance matrices or between one single factor and a matrix (Euclidean dissimilarities distance for chemical variables and Bray-Curtis distance for the life-form community composition).

\section{Results and Discussion}

\subsection{Soil Physico-Chemical Properties}

Some physicochemical properties exhibited statistically significant differences between the organic and integrated plots already at T0 (Supplementary material, Table S1) in the Inter-row and Row positions. According to the USDA (U.S. Department of Agriculture) texture classification, the soil from the Integrated plot was silty-loam (SiLo), whereas the Organic soil was sandy-loam (SaLo). The textural composition, particularly clay and silt, may affect microbial composition [36] and thereby influence the restoration of the microbial community [33]. Some differences were observed in the soil chemical characteristics between management systems and position over time. The available Mn was significantly different in the two management systems (Int $=6.1 \pm 0.5 \mathrm{mg} / \mathrm{kg} \mathrm{d.w.,} \mathrm{Org}=7.7 \pm 0.4 \mathrm{mg} / \mathrm{kg} \mathrm{d.w.,}$ $p$-value 0.0410) in the Inter-row at T2. In the Row, but not in the Inter-row, the assimilable P (Int = $184 \pm 14 \mathrm{mg} / \mathrm{kg}$ d.w., Org $=97 \pm 7 \mathrm{mg} / \mathrm{kg} \mathrm{d.w.)} \mathrm{differed} \mathrm{statistically}$ $(p$-value $=0.0005)$ at T0 and T2. The available $\mathrm{Cu}$ concentration was similar between management systems and positions at T0 (Inter-row $p$-value $=0.8499$, Row $p$-value $=0.5204$ ) Due to the more frequent treatment with $\mathrm{Cu}$-based products on the canopy like fungicides in the organic plot, the $\mathrm{Cu}$ available concentration increased and it was significantly different ( $p$-value $=0.0376)$ in Org-R $(42 \pm 4 \mathrm{mg} / \mathrm{kg}$ d.w.) compared with the Integrated plot (32 $\pm 2 \mathrm{mg} / \mathrm{kg}$ d.w.) at T2 (Supplementary material, Table S2). No differences were observed for the other chemical elements between management systems, positions and times.

\subsection{Effects of Agricultural Practices on Fungal Soil Communities}

In all investigated soils, 267 fungi genera were found, where the more representative genera were Mortierella (6.3\%), Tetracladium (2.8\%), Guehomyces (2.1\%), Coprinellus (1.7\%), Cylindrocarpon (1.6\%), Nectria (1.6\%), Ilyonectria (1.5\%), Myrothecium (1.2\%) and Cladorrhinum $(1.1 \%)$ (Figure 1a), which are the most characteristic groups found in exploited agricultural soils. Indeed, Mortierella, Tetracladium, Cylindrocarpon and Nectria are among the main agents that cause replanting diseases, root rot and cancer in apple orchards [12]. At time T0, the Bray-Curtis distance between Org and Int for fungal communities was higher than the management distance for bacterial communities (Inter-row: fungi $=0.41$, bacteria $=0.31$; Row: fungi $=0.46$, bacteria $=0.31$ ) (Figure 2$)$. These data suggested that fungi were more susceptible to the soil structure (chemical parameters) than bacteria, which seemed more stable in the soil than the fungi. Different texture compositions of soil might explain much of the variation seen in the structure and diversity of the fungi under these two types of management. Indeed, some soil properties, such as soil texture, $\mathrm{pH}$ and element concentrations chemical properties, including $\mathrm{Cu}$ and $\mathrm{P}$, were implicated as important factors in shaping microbial communities [37,38]. Moreover, Whalen et al. [11] showed that the availability of some elements promotes variability in fungal community composition (e.g., Mn). In this study, we detected differences between the Organic and Integrated plots for $\mathrm{Mn}$ and $\mathrm{Cu}$. At T0, neither of these elements differed between the two management methods, but the $\mathrm{Cu}$ concentration increased during the experimentation, in particular in Row, and at T2, we detected significant differences between Org and Int. The same trend was observed for Mn (Supplementary material, Table S1). The increase in these two elements and the consequent selection action on fungi community [11,35] could explain the Bray-Curtis distance increment from T0 to T1 and T2 (Figure 2). The analysis of the biodiversity indices (Table 1) did not show any differences between Int and Org in the Inter-row position. In the Row, all indices decreased in Int-R, but only S.Chao1 showed a significant reduction over time (Table 1 ). In contrast, in Org- $\mathrm{R}$, the indices $\mathrm{S}, \mathrm{H}^{\prime}$ and J increased significantly over time (Table 1). The opposite trends observed between Org-R 
and Int-R could have been due to the two different soil managements and practices. Int- $R$ was characterized by mineral fertilization and chemical weeding with glyphosate and other herbicides. Soil features, such as CEC, clay content and SOM, affect the glyphosate degradation rate and its persistence in soil, while its effects on soil microbes are doubtful and conflicting [39]. However, tillage and other mechanical practices are the primary drivers of microbial composition rather than glyphosate application [39]. In this study, the Organic plot was managed by mechanical mowing and the application of organic amendments to the Row. The use of organic amendments enhances the microbial diversity in the soil and, particularly, affects the soil fungal communities [12]. In our research, unlike what was observed in Integrated management, the fungal community of the Organic-Row plot appeared to move close to the fungal community of the Inter-row positions in T2 (Figure 3), suggesting an initial approach to a less impacted agroecosystem.

(a)

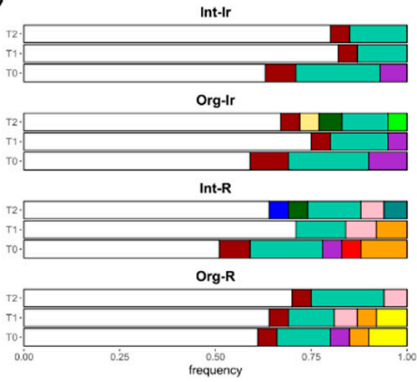

(c)
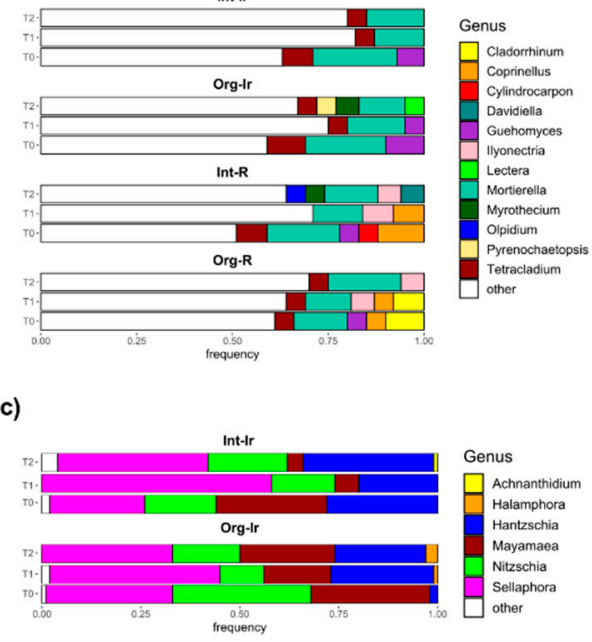

(b)

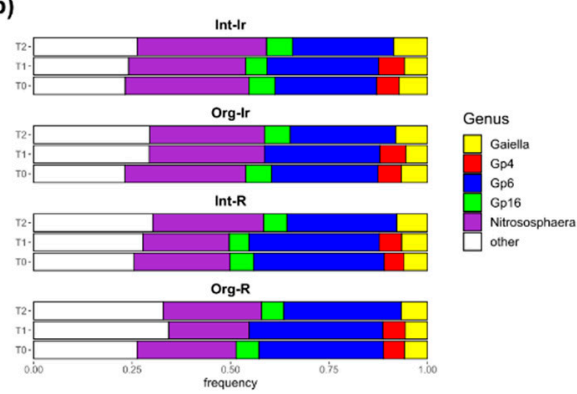

(d)

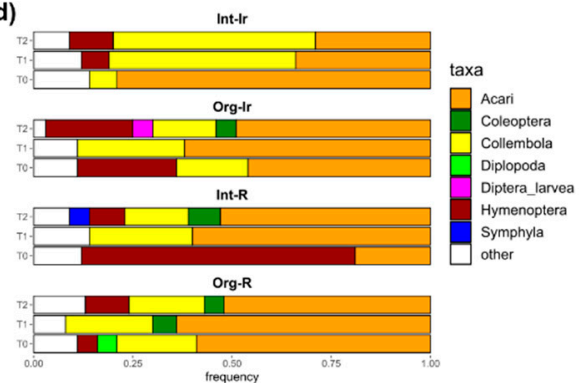

Figure 1. Frequency plots. Representative community distributions under different management systems (Organic and Integrated) on the Row and Inter-row, from T0 to T2. (a) Fungi genera: 3,958,526 sequences (ITS region) were rarefied to 18,645 reads per sample and clustered into 8606 OTUs. A total of 1552 sequences provided taxonomic information on 267 genera (18\%). (b) Bacteria genera: 5,405,403 sequences (V4 region of 16S) were generated. After rarefying, 24,180 reads out of 43,394 OTUs were obtained. A total of 8992 OTUs were associated with 408 genera (20.7\%). (c) Diatoms genera (frequency: at least $5 \%$ of the total and $1 \%$ of the total for diatoms) and (d) microarthropod taxa.

\subsection{Soil Properties Mainly Affected Bacterial Communities}

Overall, 408 bacteria genera were found within the soil samples. Nitrososphaera (10.3\%) and Gp16 (1.3\%) were the most characteristic genera (Figure 1b). Our more representative genera among the dominant groups in the agricultural soils were classified as oligotrophic bacteria [40]. The $\mathrm{P} / \mathrm{A}$ ratio $(\mathrm{P}=$ copiotrophic phyla of Proteobacteria, $\mathrm{A}=$ oligotrophic phyla of Acidobacteria) is indicative of the trophic level of the investigated soil [34] and its high values $(\geq 0.5)$ suggests a sufficient availability of nutrients in soil [33]. In this work, the P/A ratio was similar between Integrated and Organic plots in either position at the beginning of the trial (T0) (Int-IR $=0.69$, Org-IR $=0.69$, Int-R $=0.77$, Org-R = 0.77). At $\mathrm{T} 2$, this ratio was higher in the Organic than in the Integrated plot (Int-IR $=0.65$, Org-IR $=0.72$, Int-R $=0.78$, Org- $\mathrm{R}=0.82$ ), indicating an improvement of soil nutrient availability in organic management. The dissimilarity of bacteria was higher at T1 than at T0 and T2 in the Inter-row and was higher at T1 and T2 than at T0 in the Row position (Figure 2). Bacterial populations respond quickly to nutrient addition [41], but 
this response decreases over time [42]. In this study, the samplings were collected distant from cultivar operations (fertilization and weeding); this can account for the lower values of bacterial Bray-Curtis distance relative to those of the fungal community. The bacterial biodiversity indicators decreased from T0 (spring) to T2 (autumn) in both positions and this reduction was statistically significant in the Row position, showing the seasonal impact on the bacterial community [43] (Table 1). In the Inter-row position, the seasonal effect on the bacterial composition (Table 1) was reduced by the permanent grass cover, which might have limited temperature and moisture variation in soil [44]. Additionally, bacterial biodiversity indices and total carbonate content, which were higher in the Inter-row than in the Row positions, were positively correlated (Supplementary material, Table S2); this result underlines the positive effect of carbonates on bacterial biodiversity [45]. The bacterial community composition showed a separation between the Inter-row and Row positions for both management systems, except for the Organic system at T2 (Figure 3).

(a)
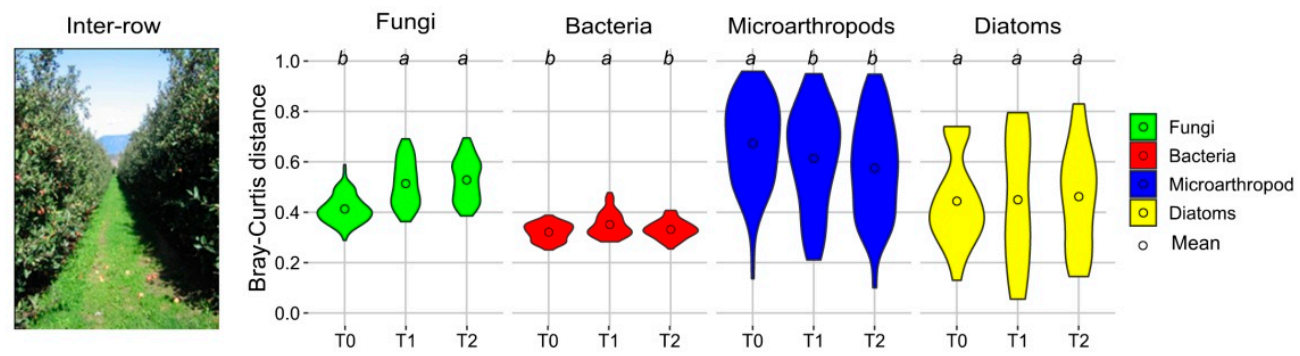

(b)
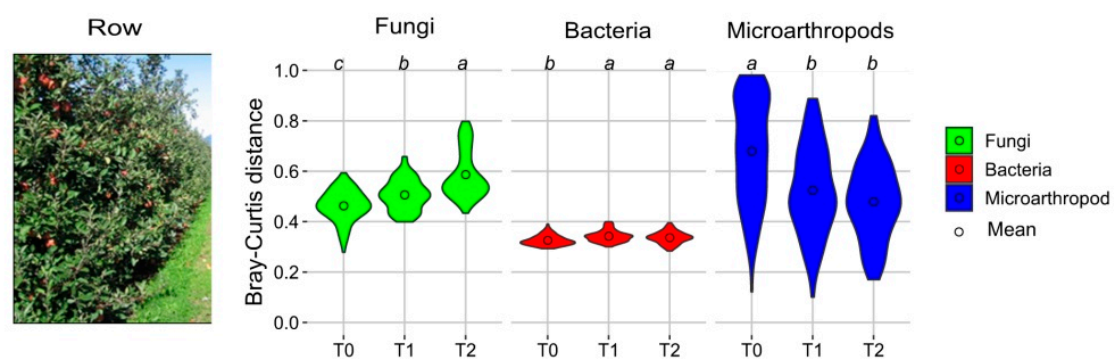

Figure 2. Violin plot of the Bray-Curtis distance between Integrated and Organic managements for soil community: (a) Inter-row position and (b) Row position. The Bray-Curtis dissimilarity was used to quantify the difference/distance between treatments in the same position. This measure took on values from 0 (identical samples) to 1 (completely disjointed samples). 
Table 1. Table of biodiversity indices (mean \pm standard error). Letters in parentheses represent the results of the non-parametric Wilcoxon test with a BY correction between times in relation to treatment and position. Different letters indicate significant differences between times for the same position and management $(p \leq 0.005)$.

\begin{tabular}{|c|c|c|c|c|c|c|c|c|c|c|c|c|c|}
\hline Organism & Index & Int-Ir-T0 & Int-Ir-T1 & Int-Ir-T2 & Org-Ir-T0 & Org-Ir-T1 & Org-Ir-T2 & Int-R-T0 & Int-R-T1 & Int-R-T2 & Org-R-T0 & Org-R-T1 & Org-R-T2 \\
\hline \multirow{3}{*}{ Fungi } & $\mathrm{S}$ & $104 \pm 16$ & $1046 \pm 37$ & $1035 \pm 20$ & $1003 \pm 19$ & $976 \pm 37$ & $998 \pm 30$ & $967 \pm 21$ & $994 \pm 26$ & $896 \pm 45$ & $902 \pm 30$ (b) & $968 \pm 27(a b)$ & $977 \pm 47$ (a) \\
\hline & S.Chao1 & $1703 \pm 40$ & $1755 \pm 82$ & $1768 \pm 47$ & $1680 \pm 25$ & $1612 \pm 66$ & $1689 \pm 60$ & $1722 \pm 40$ (a) & $\begin{array}{c}1696 \pm 40 \\
(\mathrm{ab})\end{array}$ & $1518 \pm 77(\mathrm{~b})$ & $1572 \pm 52$ & $1631 \pm 43$ & $1662 \pm 73$ \\
\hline & $\mathrm{J}$ & $0.67 \pm 0.01$ & $0.68 \pm 0.01$ & $0.67 \pm 0.01$ & $0.66 \pm 0.01$ & $0.63 \pm 0.03$ & $0.67 \pm 0.01$ & $0.66 \pm 0.01$ & $0.66 \pm 0.01$ & $0.64 \pm 0.02$ & $\begin{array}{l}0.64 \pm 0.01 \\
\text { (b) }\end{array}$ & $\begin{array}{c}0.66 \pm 0.01 \\
(\mathrm{ab})\end{array}$ & $\begin{array}{c}0.67 \pm 0.02 \\
\text { (a) }\end{array}$ \\
\hline \multirow{3}{*}{ Bacteria } & $\mathrm{s}$ & $5452 \pm 127$ & $5508 \pm 177$ & $5243 \pm 119$ & $5379 \pm 179$ & $5499 \pm 102$ & $5477 \pm 108$ & $5916 \pm 92$ (a) & $\begin{array}{c}5802 \pm 162 \\
(\mathrm{ab})\end{array}$ & $\begin{array}{c}5463 \pm 149 \\
\text { (b) }\end{array}$ & $5991 \pm 74$ (a) & $\begin{array}{c}5863 \pm 105 \\
(\mathrm{ab})\end{array}$ & $\begin{array}{c}5686 \pm 103 \\
\text { (b) }\end{array}$ \\
\hline & $\mathrm{H}$ & $\begin{array}{l}6.99 \pm 0.06 \\
(\mathrm{ab})\end{array}$ & $\begin{array}{c}7.14 \pm 0.06 \\
\text { (a) }\end{array}$ & $\begin{array}{l}6.92 \pm 0.05 \\
\text { (b) }\end{array}$ & $7.02 \pm 0.07$ & $7.16 \pm 0.06$ & $7.10 \pm 0.06$ & $\begin{array}{l}7.33 \pm 0.03 \\
\text { (a) }\end{array}$ & $\begin{array}{l}7.38 \pm 0.04 \\
\text { (a) }\end{array}$ & $\begin{array}{l}7.16 \pm 0.06 \\
\text { (b) }\end{array}$ & $\begin{array}{c}7.33 \pm 0.05 \\
(\mathrm{ab})\end{array}$ & $\begin{array}{l}7.42 \pm 0.04 \\
\text { (a) }\end{array}$ & $\begin{array}{c}7.28 \pm 0.04 \\
\text { (b) }\end{array}$ \\
\hline & $\mathrm{J}$ & $\begin{array}{c}0.81 \pm 0.01 \\
(\mathrm{ab})\end{array}$ & $\begin{array}{c}0.83 \pm 0.01 \\
\text { (a) }\end{array}$ & $0.81 \pm 0$ (b) & $0.82 \pm 0.01$ & $0.83 \pm 0.01$ & $0.82 \pm 0.01$ & $\begin{array}{c}0.84 \pm 0.00 \\
\text { (b) }\end{array}$ & $\begin{array}{l}0.85 \pm 0.00 \\
\text { (a) }\end{array}$ & $\begin{array}{c}0.83 \pm 0.01 \\
\text { (b) }\end{array}$ & $\begin{array}{c}0.84 \pm 0.00 \\
(\mathrm{~b})\end{array}$ & $\begin{array}{l}0.86 \pm 0.00 \\
\text { (a) }\end{array}$ & $\begin{array}{c}0.84 \pm 0.00 \\
\text { (b) }\end{array}$ \\
\hline \multirow{5}{*}{ Microartrhopods } & Abundance & $\begin{array}{c}8146 \pm 4454 \\
(\mathrm{ab})\end{array}$ & $\begin{array}{c}3261 \pm 1183 \\
\text { (b) }\end{array}$ & $\begin{array}{c}7643 \pm 1665 \\
\text { (a) }\end{array}$ & $4401 \pm 740$ & $6070 \pm 2928$ & $4974 \pm 1288$ & $9776 \pm 4563$ & $3503 \pm 1041$ & $3611 \pm 415$ & $9751 \pm 3804$ & $6643 \pm 1719$ & $7305 \pm 1197$ \\
\hline & QBS & $85 \pm 7$ (a) & $65 \pm 11(b)$ & $82 \pm 7(\mathrm{ab})$ & $79 \pm 11$ & $83 \pm 10$ & $65 \pm 10$ & $114 \pm 10$ (a) & $76 \pm 10(\mathrm{~b})$ & $118 \pm 10$ (a) & $127 \pm 9(\mathrm{ab})$ & $116 \pm 10(\mathrm{~b})$ & $148 \pm 9$ (a) \\
\hline & $\mathrm{S}$ & $6.0 \pm 0.6(\mathrm{ab})$ & $5.4 \pm 0.8(\mathrm{~b})$ & $7.0 \pm 0.4$ (a) & $7.0 \pm 0.6$ & $6.0 \pm 0.7$ & $6.0 \pm 0.8$ & $8.0 \pm 0.7$ (a) & $6.0 \pm 0.6(b)$ & $8.0 \pm 0.5$ (a) & $8.7 \pm 0.7(a b)$ & $7.5 \pm 0.5$ (b) & $9.9 \pm 0.5$ (a) \\
\hline & $\mathrm{H}$ & $1.2 \pm 0.1$ & $1.1 \pm 0.1$ & $1.2 \pm 0.1$ & $1.1 \pm 0.1$ & $1.0 \pm 0.1$ & $1.1 \pm 0.1$ & $1.3 \pm 0.1(\mathrm{ab})$ & $0.9 \pm 0.2(b)$ & $1.4 \pm 0.1$ (a) & $1.4 \pm 0.1$ & $1.1 \pm 0.1$ & $1.4 \pm 0.1$ \\
\hline & $\mathrm{J}$ & $0.70 \pm 0.08$ & $0.67 \pm 0.06$ & $0.63 \pm 0.04$ & $0.60 \pm 0.05$ & $0.62 \pm 0.05$ & $0.59 \pm 0.08$ & $0.62 \pm 0.07$ & $0.53 \pm 0.06$ & $0.65 \pm 0.03$ & $0.66 \pm 0.06$ & $0.57 \pm 0.05$ & $0.63 \pm 0.04$ \\
\hline \multirow{4}{*}{ Diatoms } & $\mathrm{s}$ & $7 \pm 2$ & $6 \pm 1$ & $8 \pm 2$ & $5 \pm 1$ & $6 \pm 1$ & $6 \pm 1$ & & & & & & \\
\hline & S.Chao1 & $7 \pm 2$ & $6 \pm 1$ & $8 \pm 2$ & $5 \pm 1$ & $7 \pm 1$ & $7 \pm 1$ & & & & & & \\
\hline & $\mathrm{H}$ & $\begin{array}{c}1.20 \pm 0.07 \\
\text { (a) }\end{array}$ & $\begin{array}{c}0.84 \pm 0.05 \\
\text { (b) }\end{array}$ & $\begin{array}{c}1.12 \pm 0.07 \\
\text { (a) }\end{array}$ & $\begin{array}{c}1.16 \pm 0.03 \\
(\mathrm{~b})\end{array}$ & $1.1 \pm 0.1(\mathrm{ab})$ & $\begin{array}{c}1.31 \pm 0.03 \\
\text { (a) }\end{array}$ & & & & & & \\
\hline & $\mathrm{J}$ & $0.65 \pm 0.05$ & $0.50 \pm 0.04$ & $0.58 \pm 0.06$ & $0.73 \pm 0.02$ & $0.64 \pm 0.07$ & $0.71 \pm 0.03$ & & & & & & \\
\hline
\end{tabular}



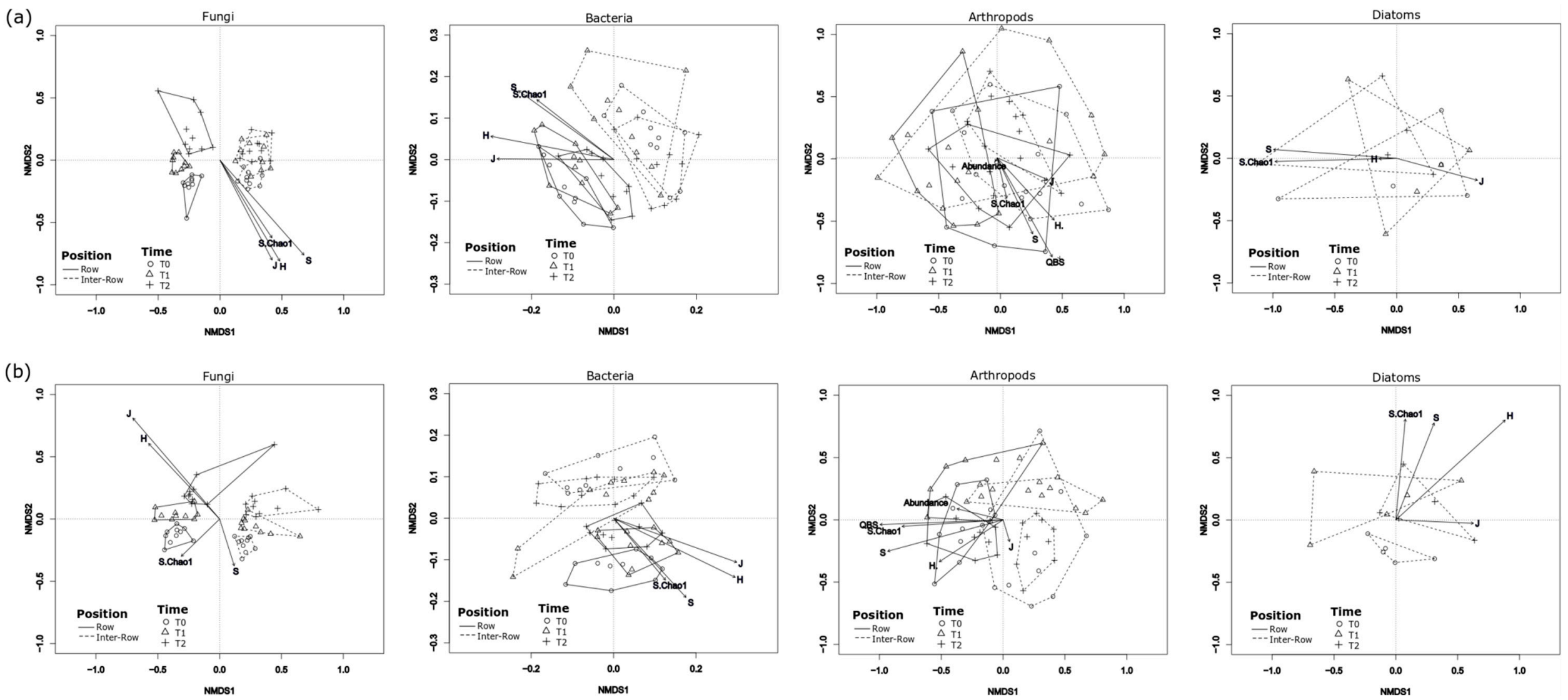

Figure 3. Results of the NMDS analyses based on the rare OTUs of the fungi and bacteria, taxa of arthropods and genera of diatoms. (a) NMDS analysis for the Integrated management. The stress values for fungi, bacteria, arthropods and diatoms were $0.1520679,0.2089021,0.2565353$ and 0.1171184 , respectively. (b) NMDS analysis for the Organic management. Fungi stress value $=0.1466064$, bacteria stress value $=0.1993824$, arthropod stress value $=0.2528133$ and diatom stress value $=0.1440569$. The Bray-Curtis dissimilarity index was used to determine the dissimilarities between the composition communities of different kingdoms. A stress value $<0.05$ provides an excellent representation in reduced dimensions, $<0.1$ is great, $<0.2$ is good and stress $<0.3$ provides a poor representation. Continuous and hatched areas were Row and Inter-row positions respectively. The shapes indicate the different times: circle $-\mathrm{T} 0$, triangle $-\mathrm{T} 1$ and cross $— \mathrm{~T} 2$. 


\subsection{Diatoms as a Promising Community for Indicating Soil Quality}

The investigation of the soil diatom community revealed a low number of taxa (28 genera), as observed by Foets et al. [17], and a high variability within replicates. Sellaphora $(38.0 \%)$, Hantzschia $(21.7 \%)$, Nitzschia $(19.5 \%)$ and Mayamaea $(18.0 \%)$ were the most abundant genera (Figure 1c). When the treatments were considered, Mayamaea had a significantly higher presence in the Organic management plot $(p$-value $=0.0201)$ than in the Integrated one, whereas the significant variations over time also affected the genera Hantzschia (increased frequency) and Nitzschia (decreased frequency) (Figure 1c), probably due to the different sensitivities of these three genera to farming practices [20]. Differences in the diatom community between the two management systems were already high at time T0 but increased over time, though not significantly (Figure 2). The biological indices increased over time in both management systems, but only for $\mathrm{H}^{\prime}$ was the difference statistically significant. It increased from T0 to T2 in Org, and at T2, it was also statistically different between management systems (Table 1). The higher value of this index in the Organic system as against the Integrated one agreed with the study of Heger et al. [24]. The change in the agricultural system affected the diatom community composition; indeed, it was different at T0 relative to T1 and T2 only in the Organic system (Figure 3). These results could be explained by the change in agricultural systems, but may also hide seasonal variations, as observed for agricultural soil [17]. The soil diatom variability significantly correlated with organic matter and total $\mathrm{N}$ in both management systems and with CSC, total $\mathrm{C}$ and exchangeable $\mathrm{Mg}$ in the Integrated system (Supplementary material, Table S2), confirming the effects of nutrients, ionic strength and other chemical elements on soil diatom distribution [25]. Terrestrial diatom species are not so well known, and some applications based on them use diatom indices developed for freshwater ecosystems [21]. More studies are needed to produce a "soil diatom index" that is able to evaluate soil quality and anthropic disturbance.

\subsection{Effect of Seasonality on Microarthropods}

A total of 11789 microarthropod specimens belonging to 16 taxa were collected. Acari were the most dominant group (50.1\%), followed by Collembola $(21.1 \%)$ and adults of Hymenoptera (15.0\%) (Figure 1d). The total microarthropod abundance decreased over time in both management systems along the Row, and there was a significant reduction from $\mathrm{T} 0$ and T1 in the Int-Ir plot (Table 1). For the microarthropod community, the Bray-Curtis distance between the two treatments decreased from T0 to T1 and T2 in both positions (Figure 2). Moreover, at all sampling times, the variability of arthropods in the distances was much higher than fungi, bacteria and diatoms. In the short-term, seasonality and differences in soil properties had a more significant role in determining arthropod community compared to agronomic management [46]. Temperature and moisture fluctuations induce vertical migration through the soil profile, causing a variable distribution of soil microarthropods in soil [47]. The richness and the evenness indices showed some significant differences between the times under different conditions and the QBS-ar index highlighted differences between $\mathrm{T} 1$ and the other two times (Table 1$)$. At $\mathrm{T} 1$, the biodiversity indices $\left(\mathrm{H}^{\prime}\right.$ and $\left.\mathrm{J}\right)$ showed the lowest values. The climatic conditions at T1, such as the absence of precipitation in a month and the lowering of the temperature, could have contributed to this decrease (Supplementary material, Figure S2). These results agree with other studies that showed the strong effect of seasonality on soil arthropods [48]. In this study, no differences were found between the Integrated and Organic plots in the biodiversity indices of the microarthropod community (Figure 3). We hypothesized that two years after the conversion is not enough time to detect a significant change in the soil arthropod community.

\section{Conclusions}

This study considered three sampling time points and four different soil communities (fungi, bacteria, arthropods and diatoms) to evaluate the differences during the conversion from integrated to organic practices in an apple orchard. The fungal communities reacted 
quickly to the change in the management system and the values of the biodiversity indices in the organic plot increased compared to the values in the Integrated one. When the change in the agricultural system was first implemented, bacterial and microarthropod communities were influenced more by the seasonality, texture and chemical properties of soil, rather than by distinct farming practices. Diatoms were found to be promising for monitoring changes in the soil since they were sensitive to both the nature of the soil and anthropic disturbance at the genus level. This study highlighted that different components of the soil living community responded in different ways to the change in management system and this result is particularly important in soil monitoring plans. The monitoring of the situation is still ongoing to better characterize the change in the soil microbiota during an agroecosystem conversion.

Supplementary Materials: The following are available online at https://www.mdpi.com/article/ 10.3390/su14010383/s1, Figure S1: Rarefaction curves of alpha diversity of the (A) number of observed bacterial OTUs, (B) number of observed fungal OTUs. Figure S2: Plots of the temperature and rain from T0 to the 30 days before sampling: (A) daily rainfall, (B) accumulated amount of rain and (C) gradient of soil temperature (geom_ridgeline_gradient \{ggridges\} of the R program). Meteorological data from the sampling areas were recorded daily in four stations located in proximity to the apple orchard. Table S1: Concentrations of the sand, silt, clay, heavy metals and other chemical parameters according to the management types, positions and times. Different letters in parentheses indicate significant differences between times for the same position and management (Wilcoxon test with BY correction, $p$-value $\leq 0.05$ ). Table S2: Spearman rank correlations ( $\mathrm{R}$ values) of single chemical variables with matrices of bacterial, fungal and microarthropod community composition and soil processes based on Mantel tests. Significance levels: ${ }^{* *} p<0.001,{ }^{* *} p<0.01$ and ${ }^{*} p \leq 0.05$.

Author Contributions: Conceptualization, C.I., C.M.O.L. and R.Z.; formal analysis, E.C.; funding acquisition, C.I.; investigation, R.M., S.Z., F.C., C.C., M.C.C.I. and C.M.O.L.; data curation, M.P. and E.C.; writing-original draft preparation, E.C., C.M.O.L., C.M. and R.M. All authors have read and agreed to the published version of the manuscript.

Funding: This research (project MELOBIO 2018/2020) was sponsored by the Autonomous Province of Trento (PAT) to support research and divulgation in sustainable agriculture, new biotechnologies and organic agriculture.

Institutional Review Board Statement: Not applicable.

Informed Consent Statement: Not applicable.

Data Availability Statement: Data are available upon request.

Acknowledgments: We thank the Azienda Agricola Fondazione E. Mach and the Fondazione de Bellat for providing access to the apple orchard. We are grateful to Enzo Mescalchin for his support and Silvia Gugole for helping with fieldwork.

Conflicts of Interest: The authors declare no conflict of interest. The funders had no role in the design of the study; in the collection, analyses, or interpretation of data; in the writing of the manuscript; or in the decision to publish the results.

\section{References}

1. Lavelle, P.; Decaëns, T.; Aubert, M.; Barot, S.; Blouin, M.; Bureau, F.; Margerie, P.; Mora, P.; Rossi, J.P. Soil invertebrates and ecosystem services. Eur. J. Soil Biol. 2006, 42, S3-S15. [CrossRef]

2. Zimmerer, K.S. Biological diversity in agriculture and global change. Annu. Rev. Environ. Resour. 2010, 35, 137-166. [CrossRef]

3. Vischetti, C.; Casucci, C.; De Bernardi, A.; Monaci, E.; Tiano, L.; Marcheggiani, F.; Ciani, M.; Comitini, F.; Marini, E.; Taskin, E.; et al. Sub-Lethal Effects of Pesticides on the DNA of Soil Organisms as Early Ecotoxicological Biomarkers. Front. Microbiol. 2020, 11, 1892. [CrossRef]

4. Yang, T.; Lupwayi, N.; Marc, S.A.; Siddique, K.H.M.; Bainard, L.D. Anthropogenic drivers of soil microbial communities and impacts on soil biological functions in agroecosystems. Glob. Ecol. Conserv. 2021, 27, e01521. [CrossRef]

5. Ouyang, Y.; Norton, J.M. Short-term nitrogen fertilization affects microbial community composition and nitrogen mineralization functions in an agricultural soil. Appl. Environ. Microbiol. 2020, 86, e02278-19. [CrossRef] 
6. Qaswar, M.; Dongchu, L.; Jing, H.; Tianfu, H.; Ahmed, W.; Abbas, M.; Lu, Z.; Jiangxue, D.; Khan, Z.H.; Ullah, S.; et al. Interaction of liming and long-term fertilization increased crop yield and phosphorus use efficiency (PUE) through mediating exchangeable cations in acidic soil under wheat-maize cropping system. Sci. Rep. 2020, 10, 19828. [CrossRef]

7. Tully, K.L.; McAskill, C. Promoting soil health in organically managed systems: A review. Org. Agric. 2020, 10, 339-358. [CrossRef]

8. Garciá-Orenes, F.; Morugań-Coronado, A.; Zornoza, R.; Scow, K. Changes in soil microbial community structure influenced by agricultural management practices in a Mediterranean agro-ecosystem. PLoS ONE 2013, 8, e80522. [CrossRef]

9. Luo, X.; Wang, M.K.; Hu, G.; Weng, B. Seasonal change in microbial diversity and its relationship with soil chemical properties in an orchard. PLoS ONE 2019, 14, e0215556. [CrossRef]

10. Coller, E.; Cestaro, A.; Zanzotti, R.; Bertoldi, D.; Pindo, M.; Larger, S.; Albanese, D.; Mescalchin, E.; Donati, C. Microbiome of vineyard soils is shaped by geography and management. Microbiome 2019, 7, 140. [CrossRef]

11. Whalen, E.D.; Smith, R.G.; Grandy, A.S.; Frey, S.D. Manganese limitation as a mechanism for reduced decomposition in soils under atmospheric nitrogen deposition. Soil Biol. Biochem. 2018, 127, 252-263. [CrossRef]

12. Liang, B.; Ma, C.; Fan, L.; Wang, Y.; Yuan, Y. Compost amendment alters soil fungal community structure of a replanted apple orchard. Arch. Agron. Soil Sci. 2020, 67, 739-752. [CrossRef]

13. Schloter, M.; Dilly, O.; Munch, J.C. Indicators for evaluating soil quality. Agric. Ecosyst. Environ. 2003, 98, 255-262. [CrossRef]

14. Harkes, P.; Suleiman, A.K.A.; van den Elsen, S.J.J.; de Haan, J.J.; Holterman, M.; Kuramae, E.E.; Helder, J. Conventional and organic soil management as divergent drivers of resident and active fractions of major soil food web constituents. Sci. Rep. 2019, 9, 13521. [CrossRef] [PubMed]

15. Menta, C.; Conti, F.D.; Fondón, C.L.; Staffilani, F.; Remelli, S. Soil arthropod responses in agroecosystem: Implications of different management and cropping systems. Agronomy 2020, 7, 982. [CrossRef]

16. Mantoni, C.; Pellegrini, M.; Dapporto, L.; Del Gallo, M.; Pace, L.; Silveri, D.; Fattorini, S. Comparison of Soil Biology Quality in Organically and Conventionally Managed Agro-Ecosystems Using Microarthropods. Agriculture 2021, 11, 1022. [CrossRef]

17. Joimel, S.; Schwartz, C.; Bonfanti, J.; Hedde, M.; Krogh, P.H.; Pérès, G.; Pernin, C.; Rakoto, A.; Salmon, S.; Santorufo, L.; et al. Functional and Taxonomic Diversity of Collembola as Complementary Tools to Assess Land Use Effects on Soils Biodiversity. Front. Ecol. Evol. 2021, 9, 630919. [CrossRef]

18. Simoni, S.; Caruso, G.; Vignozzi, N.; Gucci, R.; Valboa, G.; Pellegrini, S.; Palai, G.; Goggioli, D.; Gagnarli, E. Effect of long-term soil management practices on tree growth, yield and soil biodiversity in a high-density olive agro-ecosystem. Agronomy 2021, 11, 1036. [CrossRef]

19. Meyer, S.; Kundel, D.; Birkhofer, K.; Fliessbach, A.; Scheu, S. Soil microarthropods respond differently to simulated drought in organic and conventional farming systems. Ecol. Evol. 2021, 11, 10369-10380. [CrossRef]

20. Foets, J.; Wetzel, C.E.; Teuling, A.J.; Pfister, L. Temporal and spatial variability of terrestrial diatoms at the catchment scale: Controls on productivity and comparison with other soil algae. PeerJ 2020, 8, e8296. [CrossRef]

21. Barragán, C.; Wetzel, C.E.; Ector, L. A standard method for the routine sampling of terrestrial diatom communities for soil quality assessment. J. Appl. Phycol. 2018, 30, 1095-1113. [CrossRef]

22. Bérard, A.; Rimet, F.; Capowiez, Y.; Leboulanger, C. Procedures for Determining the Pesticide Sensitivity of Indigenous Soil Algae: A Possible Bioindicator of Soil Contamination? Arch. Environ. Contam. Toxicol. 2004, 46, 24-31. [CrossRef] [PubMed]

23. Antonelli, M.; Wetzel, C.E.; Ector, L.; Teuling, A.J.; Pfister, L. On the potential for terrestrial diatom communities and diatom indices to identify anthropic disturbance in soils. Ecol. Indic. 2017, 75, 73-81. [CrossRef]

24. Heger, T.J.; Straub, F.; Mitchell, E.A.D. Impact of farming practices on soil diatoms and testate amoebae: A pilot study in the DOK-trial at Therwil, Switzerland. Eur. J. Soil Biol. 2012, 49, 31-36. [CrossRef]

25. Zhang, Y.; Ouyang, S.; Nie, L.; Chen, X. Soil diatom communities and their relation to environmental factors in three types of soil from four cities in central-west China. Eur. J. Soil Biol. 2020, 98, 103175. [CrossRef]

26. Caporaso, J.G.; Lauber, C.L.; Walters, W.A.; Berg-Lyons, D.; Lozupone, C.A.; Turnbaugh, P.J.; Fierer, N.; Knight, R. Global patterns of 16S rRNA diversity at a depth of millions of sequences per sample. Proc. Natl. Acad. Sci. USA 2011, 108, 4516-4522. [CrossRef] [PubMed]

27. Apprill, A.; Mcnally, S.; Parsons, R.; Weber, L. Minor revision to V4 region SSU rRNA 806R gene primer greatly increases detection of SAR11 bacterioplankton. Aquat. Microb. Ecol. 2015, 75, 129-137. [CrossRef]

28. Parada, A.E.; Needham, D.M.; Fuhrman, J.A. Every base matters: Assessing small subunit rRNA primers for marine microbiomes with mock communities, time series and global field samples. Environ. Microbiol. 2016, 18, 1403-1414. [CrossRef]

29. Walters, W.; Hyde, E.R.; Berg-lyons, D.; Ackermann, G.; Humphrey, G.; Parada, A.; Gilbert, J.A.; Jansson, J.K. Transcribed Spacer Marker Gene Primers for Microbial Community Surveys. mSystems 2016, 1, e0009-15. [CrossRef]

30. Gardes, M.; Bruns, T.D. ITS primers with enhanced specificity for basidiomycetes-Application to the identification of mycorrhizae and rusts. Mol. Ecol. 1993, 2, 113-118. [CrossRef]

31. White, T.J.; Bruns, T.; Lee, S.; Taylor, J. Amplification and Direct Sequencing of Fungal Ribosomal RNA Genes for Phylogenetics. In PCR Protocols: A Guide to Methods Applications; Innis, M.A., Gelfand, D.H., Snisky, J.J., White, T.J., Eds.; Academic Press: New Yourk, NY, USA, 1990; pp. 315-322.

32. Wang, Q.; Garrity, G.M.; Tiedje, J.M.; Cole, J.R. Naïve Bayesian classifier for rapid assignment of rRNA sequences into the new bacterial taxonomy. Appl. Environ. Microbiol. 2007, 73, 5261-5267. [CrossRef] [PubMed] 
33. Parisi, V.; Menta, C.; Gardi, C.; Jacomini, C.; Mozzanica, E. Microarthropod communities as a tool to assess soil quality and biodiversity: A new approach in Italy. Agric. Ecosyst. Environ. 2005, 105, 323-333. [CrossRef]

34. Menta, C.; Conti, F.D.; Pinto, S.; Bodini, A. Soil Biological Quality index (QBS-ar): 15 years of application at global scale. Ecol. Indic. 2018, 85, 773-780. [CrossRef]

35. R Core Development Team. R: A Language and Environment for Statistical Computing; R Foundation for Statistical Computing: Vienna, Austria, 2019.

36. Seaton, F.M.; George, P.B.L.; Lebron, I.; Jones, D.L.; Creer, S.; Robinson, D.A. Soil textural heterogeneity impacts bacterial but not fungal diversity. Soil Biol. Biochem. 2020, 144, 107766. [CrossRef]

37. Cloutier, M.L.; Murrell, E.; Barbercheck, M.; Kaye, J.; Finney, D.; García-González, I.; Bruns, M.A. Fungal community shifts in soils with varied cover crop treatments and edaphic properties. Sci. Rep. 2020, 10, 6198. [CrossRef] [PubMed]

38. Bach, E.M.; Baer, S.G.; Meyer, C.K.; Six, J. Soil texture affects soil microbial and structural recovery during grassland restoration. Soil Biol. Biochem. 2010, 42, 2182-2191. [CrossRef]

39. Kepler, R.M.; Epp Schmidt, D.J.; Yarwood, S.A.; Cavigelli, M.A.; Reddy, K.N.; Duke, S.O.; Bradley, C.A.; Williams, M.M.; Maula, J.E. Soil microbial communities in diverse agroecosystems exposed to the herbicide glyphosate. Appl. Environ. Microbiol. 2020, 86, e01744-19. [CrossRef] [PubMed]

40. Yang, J.; Duan, Y.; Zhang, R.; Liu, C.; Wang, Y.; Li, M.; Ding, Y.; Awasthi, M.K.; Li, H. Connecting soil dissolved organic matter to soil bacterial community structure in a long-term grass-mulching apple orchard. Ind. Crops Prod. 2020, 149, 112344. [CrossRef]

41. Liang, B.; Ma, C.; Fan, L.; Wang, Y.; Yuan, Y. Soil amendment alters soil physicochemical properties and bacterial community structure of a replanted apple orchard. Microbiol. Res. 2018, 216, 1-11. [CrossRef]

42. Girvan, M.S.; Bullimore, J.; Ball, A.S.; Pretty, J.N.; Osborn, A.M. Responses of active bacterial and fungal communities in soils under winter wheat to different fertilizer and pesticide regimens. Appl. Environ. Microbiol. 2004, 70, 2692-2701. [CrossRef]

43. Smit, E.; Leeflang, P.; Gommans, S.; Van Den Broek, J.; Van Mil, S.; Wernars, K. Diversity and Seasonal Fluctuations of the Dominant Members of the Bacterial Soil Community in a Wheat Field as Determined by Cultivation and Molecular Methods. Appl. Environ. Microbiol. 2001, 67, 2284-2291. [CrossRef]

44. Whitelaw-Weckert, M.A.; Rahman, L.; Hutton, R.J.; Coombes, N. Permanent swards increase soil microbial counts in two Australian vineyards. Appl. Soil Ecol. 2007, 36, 224-232. [CrossRef]

45. Guo, A.; Ding, L.; Tang, Z.; Zhao, Z.; Duan, G. Microbial response to $\mathrm{CaCO}_{3}$ application in an acid soil in southern China. $J$. Environ. Sci. 2019, 79, 321-329. [CrossRef] [PubMed]

46. Gkisakis, V.D.; Kollaros, D.; Bàrberi, P.; Livieratos, I.C.; Kabourakis, E.M. Soil Arthropod Diversity in Organic, Integrated, and Conventional Olive Orchards and Different Agroecological Zones in Crete, Greece. Agroecol. Sustain. Food Syst. 2015, 39, 276-294. [CrossRef]

47. Sheikh, A.A.; Rehman, N.; Bhat, T.A.; Sofi, M.A.; Bhat, M.A.; Un Nabi, S.; Aijaz, C.; Sheikh, A.; Lone, G.; Sofi, A. Vertical distribution of soil arthropods in apple ecosystem of Kashmir. J. Entomol. Zool. Stud. JEZS 2017, 843, 843-846.

48. Mantoni, C.; Di Musciano, M.; Fattorini, S. Use of microarthropods to evaluate the impact of fire on soil biological quality. J. Environ. Manag. 2020, 266, 110624. [CrossRef] [PubMed] 